\title{
AILANTHUS VIETNAMENSIS (SIMAROUBACEAE): A NEW SPECIES FROM VIETNAM
}

\author{
HOANG VAN SAM ${ }^{1} \&$ HANS P. NOOTEBOOM ${ }^{2}$
}

\begin{abstract}
SUMMARY
Ailanthus vietnamensis from Cuc Phuong National Park is described as a new species from Vietnam.
\end{abstract}

Key words: Ailanthus, Simaroubaceae, Vietnam.

\section{INTRODUCTION}

In collections from Vietnam that were sent to the Leiden herbarium for identification was a collection of a fruiting Ailanthus that differed from all hitherto described species in the place of the main vascular bundle towards the seed in the samara (Nooteboom, 1962: 217). We waited for flowering collections to be collected and then discovered that the species also differed in being monoecious with male and bisexual flowers in stead of dioecious. Also in the flowers differences are found, like the number of carpels being two.

Ailanthus vietnamensis H.V. Sam \& Noot., spec. nov. - Fig. 1

A speciibus aliis Ailanthi differt planta monoecia est floribus masculis et bisexualibus. Foliola 6-10-juga, integra, subtus glandulis parvis applanatis sparse munita. Pedicelli 7 vel $10 \mathrm{~mm}$ longi. Carpelli 2, dense pubescentes stylis liberis. Samara 7-10 cm longa; fasciculus vasorum seminem versus intramarginalis, styli cicatryx basi opposita. - Typus: Nguyen Manh Cuong NMC_1650 (holo L; iso F), Vietnam, Thanh Hoa Province, Thach Thanh District, Cuc Phuong National Park.

Monoecious tree, $8 \mathrm{~m}$ high, dbh $20 \mathrm{~cm}$; bark yellowish grey, smooth; twigs very stout, yellowish green to brown, rusty puberulous, lenticels ochre-coloured, leaf scars large, heart-shaped. Leaves spirally arranged, pinnate, up to $45 \mathrm{~cm}$ long, clustered near the end of the twig with 6-10 pairs of opposite leaflets; petiole 4-11 cm long, puberulous; leaflets entire, obliquely narrowly ovate $5-11$ by $1.5-3.5 \mathrm{~cm}$, glabrous above, sometimes more or less pubescent beneath, apex acuminate with an obtuse tip, lateral nerves 6-16(-18) pairs, midrib and lateral nerves prominent on the undersurface, pubescent, usually a few black, flat round or elliptic glands on the undersurface,

1) Forest Plant Department, Vietnam Forestry University, Xuan Mai, Hatay, Vietnam; e-mail: hsamfuv@yahoo.com.

2) Nationaal Herbarium Nederland, Universiteit Leiden branch, P.O. Box 9514, 2300 RA Leiden, The Netherlands. 


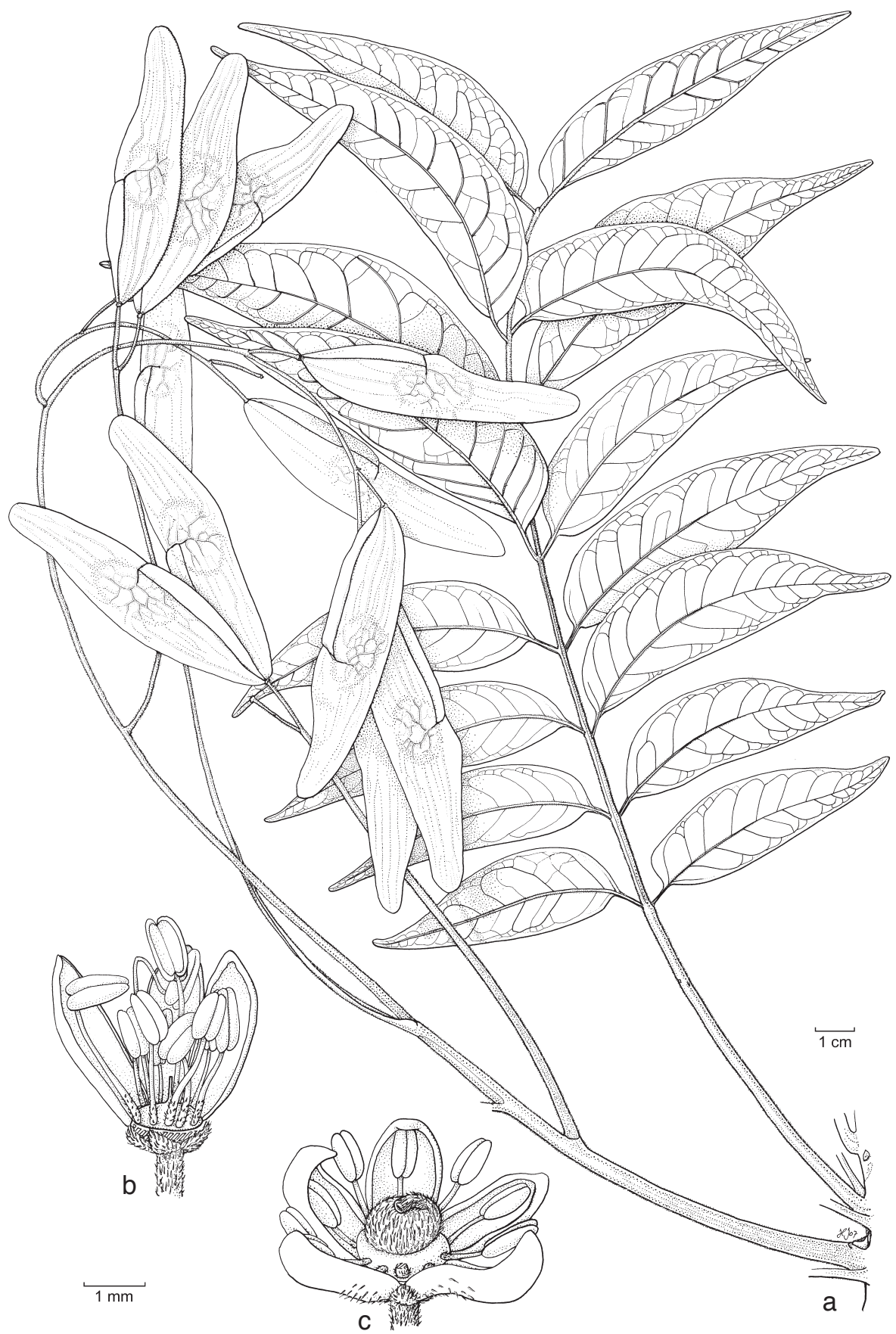

Fig. 1. Ailanthus vietnamensis H.V. Sam \& Noot. a. Leaf and infructescence; b. male flower; c. bisexual flower (a: Nguyen Manh Cuong NMC_1650 (L); b, c: Nguyen Manh Cuong NMC 2110 (L). 
especially on the nerves; petiolules $0.5-1 \mathrm{~cm}$ long, puberulous. Inflorescences axillary panicles, up to $19 \mathrm{~cm}$ long, puberulous to pubescent; bract small, triangular, $1.5-2$ by 2-4 mm, caducous. Flowers male or bisexual; male flower 5- (or 6-)merous, pedicels up to $15 \mathrm{~mm}$ long, puberulous; calyx 5- (or 6-)lobed, the lobes longer than the tube, more or less puberulous, closed in bud, 2-3 mm high, rarely caducous; petals 5 (or 6), induplicate-valvate in bud, elliptic, $1.5-2$ by $4-5 \mathrm{~mm}$, creamish, glabrous or sparsely pubescent; stamens 10, inserted below the outer margin of the disk, filaments with many long spreading hairs to glabrous, thickened downwards, 4-7 mm long in male and $1-3 \mathrm{~mm}$ in bisexual flowers, anthers oblong, 4-lobed, $0.5-0.7$ by $0.9-1.2 \mathrm{~mm}$; bisexual flowers with hairy pedicels up to $7 \mathrm{~mm}$ long; ovary 2-carpelled, superior, dome-shaped, densely hairy, $1.5-1.8$ by $1.5-2 \mathrm{~mm}$, styles 2 , free, inserted above the middle on the adaxial side, $2-3 \mathrm{~mm}$ long, stigma's free; ovule 1, epitropous, adaxially attached in the middle. Fruit a samara, narrowly elliptic, 7-10 by $1.7-2.4 \mathrm{~cm}, 2$ (or sometimes 1) from each flower on a long slender stalk, with a thin wing surrounding a single flat seed, main vascular bundle towards the seed intramarginal, scar of style about at same level as base of the seed. Pedicel 3-10 cm long.

Distribution - Cuc Phuong National Park, Thach Thanh district, Thanh Hoa Province, Vietnam, endemic.

Ecology - Primary forest in Limestone Mountain. Flowering: March to May; fruiting: May to July.

Note - In the keys (Nooteboom, 1962: 216) this species keys out as follows:

\section{KEY TO FLOWERING SPECIMENS}

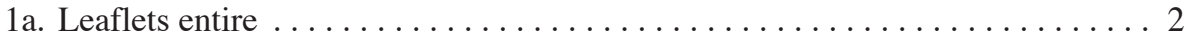

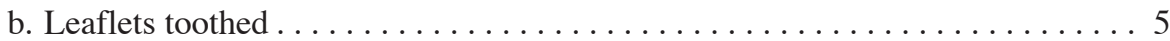

2a. Petals puberulous. Carpels 5. Leaflets usually with a few large black glands ....

A. integrifolia

b. Petals glabrous or sparsely pubescent. Carpels $2-4$ or 5. Leaflets without glands or with some small glands . . . . . . . . . . . . . . . 3

3a. Calyx lobes as long as or longer than the tube. Carpels $2-4$, glabrous or hairy.

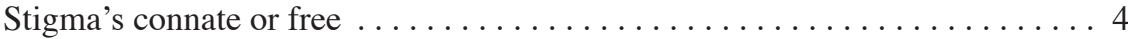

b. Calyx lobes shorter than the tube. Carpels 5, puberulous, stigma's free A. fordii

4a. Plant monoecious with male and bisexual flowers. Calyx lobes longer than the tube. Carpels 2, hairy. Stigma's free . . . . . . . . . . . vietnamensis

b. Plant dioecious. Calyx lobes as long as the tube or longer. Carpels 3 or 4, glabrous. Stigma's connate ....................... triphysa

\section{KEY TO FRUITING SPECIMENS}

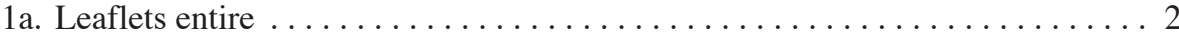

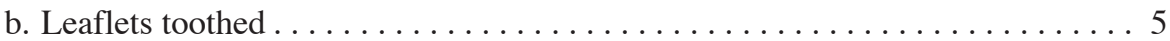

2a. Main vascular bundle towards seed in the margin of the samara A. integrifolia

b. Main vascular bundle towards seed of the samara intramarginal . . . . . . . 3

3a. Samara's 3-5 cm long, up to 5 from each flower. Main vascular bundle towards seed of the samara at the same level as the apex of the seed ...... A. fordii 
b. Samara's 4.5-10 $\mathrm{cm}$ long. Main vascular bundle towards seed of the samara at same level as the middle or the base of the seed . . . . . . . . . . . . . 4

4a. Samara's 1-2, 7-10 cm. Main vascular bundle towards seed of the samara at same level as the base of the seed

A. vietnamensis

b. Samara's 1-3(-4), 4.5-7.5 cm long. Main vascular bundle towards seed of the samara at the same level as the middle of the seed ........... A. triphysa

Specimens examined:

Nguyen Manh Cuong NMC_1650(L), NMC 2110 (L).

\section{ACKNOWLEDGEMENTS}

The authors are grateful to the Vietnamese government for financial support of Mr. Hoang Van Sam to carry out his study at Leiden University. We would like to thank Nguyen Manh Cuong (Cuc Phuong National Park) for collection the specimens and Duong Thi Bich Ngoc (Vietnam Forestry University) for sending the specimens to Leiden. Hanneke Felles made the beautiful drawing.

\section{REFERENCE}

Nooteboom, H.P. 1962. Simaroubaceae. Flora Malesiana, Ser. I, 6: 193-226. Noordhoff International publishing, Leyden, The Netherlands. 